\title{
东秦岭方城新元古代碱性正长岩形成时代及其 动力学意义
}

包志伟 ${ }^{\circledR}$, 王强 ${ }^{(}$, 白国典 $\left.{ }^{(}\right)$, 赵振华 ${ }^{\circledR}$, 宋要武 ${ }^{(3)}$, 柳小明 ${ }^{(}$

(1) 中国科学院广州地球化学研究所成矿动力学实验室, 广州 510640 ;

(2) 中国科学院广州地球化学研究所同位素年代学与地球化学重点实验室, 广州 510640;

(3) 河南省地质调查院, 郑州 450007;

(4) 西北大学地质学系大陆动力学国家重点实验室, 西安 710069

E-mail: baozw@gig.ac.cn

2007-11-12 收稿, 2007-12-06 接受

国家自然科学基金(批准号: 40472032, 40721063, 40672070)、国家重点基础研究发展计划(批准号: 2006CB403504)和中国科学院知识创新工 程(批准号: KZCX2-YW-128)资助项目

摘要 通过对秦岭造山带东段北秦岭构造域的新元古代方城碱性岩体研究, 对 Rodinia 超大 陆形成后岩石圈拉张起始时间提供了重要制约. 方城岩体岩石类型主要为角闪云霞正长岩、 霓辉正长岩和碱性长石正长岩. 岩石为中性 $\left(\mathrm{SiO}_{2}=54 \% \sim 62 \%\right)$, 富碱 $\left(\mathrm{K}_{2} \mathrm{O}+\mathrm{Na}_{2} \mathrm{O}=12 \% \sim\right.$ $15 \%) 、$ 铝 $\left(\mathrm{Al}_{2} \mathrm{O}_{3}=16.81 \%\right.$ 23.26\%)与大离子亲石元素, 无 $\mathrm{Nb}, \mathrm{Ta}, \mathrm{Zr}, \mathrm{Hf}$ 异常, 轻稀土元素相 对富集、重稀土元素分异较弱, 呈较显著的负 $\mathrm{Eu}$ 异常 $(\delta \mathrm{Eu}=0.13 \sim 0.23)$, 其 $\varepsilon_{\mathrm{Nd}}(t)$ 值为 $-1.37 \sim$ $-3.90, \mathrm{Nd}$ 模式年龄为 $1364 \sim 1569 \mathrm{Ma}$. 正长岩岩浆形成的温度较高 $\left(915 \sim 1044^{\circ} \mathrm{C}\right)$. 岩体形成于 板内-非造山伸展构造环境, 可能主要来源于上地幔的小比例部分熔融, 在上升或侵位过程中 受到少量地壳物质的混染. 方城碱性正长岩的锆石 LA-ICP-MS U-Pb 年龄为(844.3 \pm 1.6$) \mathrm{Ma}$ $(M S W D=0.86)$, 表明其形成于新元古代早期, 为秦岭造山带及华南地区已知形成时代最早 的新元古代碱性岩, 也暗示在 $844 \mathrm{Ma}$ 左右秦岭造山带新元古代构造演化已由碰撞后伸展转 换为板内非造山拉张阶段. 因此, Rodinia 拼合过程中沿扬子克拉通边缘形成的碰撞造山过程 结束并转入拉张体制地球动力学背景的时限应不晚于 $844 \mathrm{Ma}$.

关键词

新元古

Rodinia 碱性正长岩

锆石

$\mathrm{U}-\mathrm{Pb}$ 定年
秦岭造山带是华北克拉通与扬子克拉通之间的 汇聚带, 东连大别-苏鲁造山带, 西延与祁连造山带 和昆仑造山带相连, 经历了自元古代以来多次的板 片碰撞和分离过程 ${ }^{[1]}$. 秦岭是一个古生代-中生代强 烈俯冲碰撞形成的复合型大陆造山带, 但造山带中 仍保留了大量中-新元古代造山作用的遗迹. 对秦岭 造山带, 特别是自早古生代以来的形成及演化, 前人 进行了大量的研究, 并提出了多种不同的地球动力

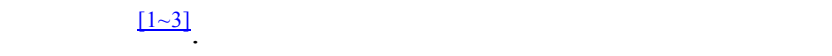
东延伸的大别-苏鲁造山带均存在众多新元古代碰撞 造山及伸展环境中岩浆岩的证据, 成为研究Rodinia 超大陆汇聚和裂解过程的热点地区 $\stackrel{[4 \sim 10]}{ }$.
前人对秦岭造山带内新元古代岩浆活动做了大 量的同位素定年工作, 为探讨秦岭造山带新元古代 构造演化奠定了基础. 松树沟蛇绿岩(全岩 $\mathrm{Sm}-\mathrm{Nd}$ 等 时线年龄 $\left.(1030 \pm 46) \mathrm{Ma}^{[111}\right)$ 的存在表明, $1000 \mathrm{Ma}$ 前 在华北克拉通与扬子克拉通之间存在一洋盆一一古 秦岭洋; 晋宁期高压变质榴辉岩、高压基性麻粒岩和 长英质麻粒岩(全岩-矿物 Sm-Nd等时线年龄 $(983 \pm$ 140) $\mathrm{Ma}^{[12,13]}$ ), 大量的同碰撞型花岗岩(商南岩体 ${ }^{[14]}$; 商丹带北侧新元古代埃达克质花岗岩 ${ }^{[15]}$; 北秦岭牛 角山、德河、寨根、石槽沟等强变形富铝的同碰撞型 花岗岩 $\left.{ }^{[4]}\right)$ 表明新元古代早期华北克拉通与扬子克拉 通在 1000 900 Ma期间发生碰撞拼合; 北秦岭蔡凹岩 
体(锆石LA-ICPMS U-Pb法年龄 $(889 \pm 10) \mathrm{Ma}$ )的变形 较弱, 为高钾钙碱性、高铝、富碱和大离子亲元素、 贫HFSE，形成于碰撞后构造环境，表明秦岭新元古 代碰撞造山作用在 $890 \mathrm{Ma}$ 已进入由主碰撞挤压转向 后碰撞伸展演化阶段 ${ }^{[16]}$; 普遍接受的作为秦岭造山 带中产于非造山环境(板内裂谷)的吐雾山A型花岗岩 (钠铁闪石花岗岩-钾长花岗岩) 锆石 $U-\mathrm{Pb}$ 年龄为 710 730 $\mathrm{Ma}^{[7,17]}$. 秦岭造山带及邻区还存在一些 890 710 Ma间的火山活动记录, 如扬子克拉通西北 缘的碧口群火山岩、南秦岭耀岭河群火山岩等, 但对 其形成的构造环境及其地球动力学意义有较大的争 议 ${ }^{[18 ~ 20]}$. 因此, 在 890 710 Ma这个长达 $180 \mathrm{Ma}$ 的漫 长地质历史中秦岭造山带是否一直处于碰撞后( postcollision) 伸展构造环境, 或者说新元古代碰撞造山 作用由碰撞后(post-collision)向非造山(板内) (anogenic/intraplate)过程的转折发生在何时, 一直是秦岭 造山带新元古代构造演化研究中悬而未决的重要科 学问题.

秦岭造山带内沿黑沟-栾川-维摩寺深断裂分布 一条碱性岩-碱性花岗岩带. 该岩带东起平午地区经 方城、南召北部, 过卢氏、栾川至陕西洛南, 长度不 小于 $400 \mathrm{~km}$, 简称栾川-方城碱性岩-碱性花岗岩带 [21]，目前具有精确同位定年的新元古碱性岩-碱性花 岗岩仅吐雾山碱性花岗岩(钠铁闪石霓辉石花岗岩及 钾长花岗岩)一处, 其形成时代为 $(711 \pm 11) \mathrm{Ma}$ (锆石 $\mathrm{U}-\mathrm{Pb}$ SHRIMP $\left.{ }^{[7]}\right) \sim(725 \pm 39) \mathrm{Ma}$ (锆石 U-Pb IDTIMS ${ }^{[17]}$ ). 我们近期对该带的方城碱性正长岩进行了 主、微量元素、Nd同位素分析和锆石LA-ICPMS U-Pb 同位素定年. 方城碱性正长岩的形成时代、构造环境 的研究对探讨新元古代秦岭造山带乃至Rodinia超大 陆的形成和演化具有重要的科学意义.

\section{1 岩体地质}

方城正长岩产于秦岭造山带东段的北秦岭构造 域，地理上位于河南省方城县县城北约 $15 \mathrm{~km}$, 出露 于方城县杨集乡塔山-双山-宋坟一带(图 1). 岩体侵 位于晚元古宙(相当于清白口系)栾川群南泥湖组和 煤窑沟组 $\left(\sim 800\right.$ 至 $\left.1000 \mathrm{Ma}^{[22]}\right)$ 黑云母、绢云母石英 片岩之中(图 1). 方城正长岩出露面积约 $7 \mathrm{~km}^{2}$, 主要 由碱性长石正长岩、霓辉正长岩和角闪云霞正长岩组 成. 本次研究主要为塔山和双山岩体. 塔山岩体主体 为绢云母化正长岩, 局部为霓辉正长岩和霓霞正长 岩. 长石矿物以微斜长石为主, 微斜条纹长石次之.
暗色矿物主要为霓石及少量霓辉石和镁质黑云母. 岩体蚀变作用较强, 主要为绢云母化和绿穷石化. 双 山正长岩岩体主要为黑云母正长岩和角闪霞石正长 岩. 岩石具轻微的绢云母化和钠长石化蚀变. 黑云母 正长岩中常含有少量金云母. 长石矿物主要为微斜 长石、钠长石和微斜条纹长石. 霞石含量可达 $20 \% \pm$. 黑云母为铁质黑云母, 辉石为霓辉石, 角闪石为碱性 角闪石, 钠钙质绿闪石 [23].

\section{2 岩体地球化学特征}

方城正长岩(塔山、双山岩体)的岩石化学、微量 元素及 $\mathrm{Sm}-\mathrm{Nd}$ 同位素组成在中国科学院广州地球化 学研究所同位素年代学和地球化学重点实验室完成, 分别在Rigaku 100e型苂光光谱仪XRF, PE Elan 6000 型电感偶合等离子体-质谱仪(ICP-MS)及 Micromass Isoprobe型MC-ICPMS上分析. 详细的分析方法及流 程见Li等人文 ${ }^{[24,25]}$.

岩石的 $\mathrm{SiO}_{2}$ 含量较低, 变化范围为 $54 \% \sim 62 \%$, 富碱 $\left(\mathrm{K}_{2} \mathrm{O}+\mathrm{Na}_{2} \mathrm{O}=12 \% \sim 15 \%\right)$, 铝含量较高 $\left(\mathrm{Al}_{2} \mathrm{O}_{3}=\right.$ 16.81 23.26\%)(表 1), 霓辉正长岩的标准矿物中含刚 玉. 在 TAS 图解上, 方城正长岩落入碱性岩区(图 2), 与其矿物组成中含有碱性暗色矿物和副长石相对应, 因此，方城正长岩是典型的碱性岩. 岩石相对富 $\mathrm{Ga}$, 在花岗质岩石 $\mathrm{K}_{2} \mathrm{O}+\mathrm{Na}_{2} \mathrm{O} \sim 10000 \mathrm{Ga} / \mathrm{Al}$ 及 $\mathrm{Zr} \sim 10000$ $\mathrm{Ga} / \mathrm{Al}$ 成因分类图上方城碱性正长岩落入 $\mathrm{A}$ 型花岗岩 区(图 3). 方城碱性正长岩各岩类具有相似的稀土和 微量元素组成. 稀土元素分布模式为轻稀土富集型, 具有比较显著的 $\mathrm{Eu}$ 负异常 ( $\delta \mathrm{Eu}=0.13 \sim 0.23)$, 重稀土 元素分异不明显(图 4). 正长岩的微量元素蛛网图(图 5)显示, 除两个采自塔山正长岩体的样品由于绢云母 化等蚀变作用的影响 $\mathrm{Rb}$ 和 $\mathrm{Ba}$ 显著偏高外, 方城碱性 正长岩具有非常相似的微量元素分布模型. 岩石相 对富集大离子亲石元素, 无 $\mathrm{Nb}, \mathrm{Ta}, \mathrm{Zr}, \mathrm{Hf}$ 负异常. 在 微量元素蛛网图上, 方城碱性正长岩呈现显著的 $\mathrm{Sr}$, $\mathrm{Ba}$ 及 $\mathrm{Ti}$ 的相对亏损, 结合其 $\mathrm{Eu}$ 负异常, 表明岩浆结 晶过程早期可能存在斜长石和 $\mathrm{Ti}-\mathrm{Fe}$ 氧化物的分异.

方城碱性正长岩的 Nd同位素组成(表 2)变化范围 非常小 $\left({ }^{143} \mathrm{Nd} /{ }^{144} \mathrm{Nd}=0.511697 \sim 0.511884 ;{ }^{147} \mathrm{Sm} /\right.$ $\left.{ }^{144} \mathrm{Nd}=0.00623 \sim 0.00902\right), \varepsilon \mathrm{Nd}(t)=-1.37 \sim-3.90, \mathrm{~T}_{\mathrm{DM}}$ $=1364 \sim 1569 \mathrm{Ma} . \mathrm{Nd}$ 模式年龄小于区域基底太华群形 成年代及区内碎屑沉积岩陶湾群( 640 Ma, 栾川陶 湾)的Nd模式年龄 $\left((2117 \pm 38) \mathrm{Ma}^{[29]}\right)$. 岩石微量元素 及 $\mathrm{Nd}$ 同位素特征表明方城碱性正长岩主要来源于 

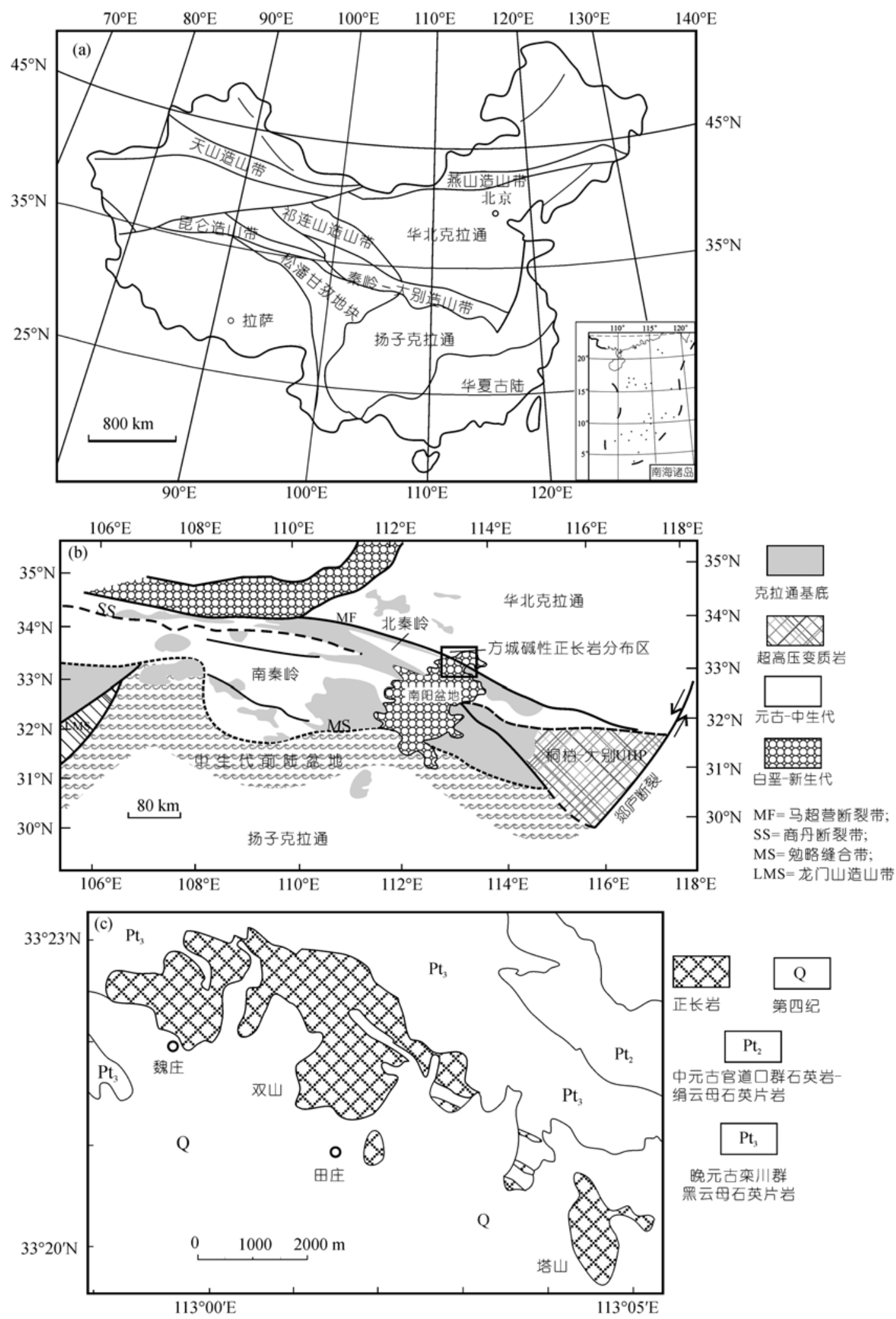

图 1 东秦岭方城晚元古代碱性正长岩所处的大地构造位置及地质略图

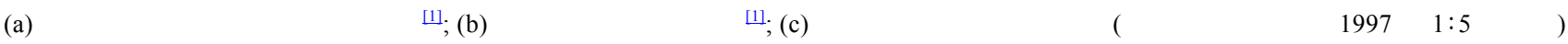


表 1 方城碱性正长岩主量、微量元素组成(主量元素单位: \%, 微量元素单位: $\mu \mathrm{g} / \mathrm{g}$ )

\begin{tabular}{|c|c|c|c|c|c|c|c|c|c|c|}
\hline 样号 & HF-1 & $\mathrm{HF}-2$ & HF-3 & HF-4 & HF-5 & HF-6 & HF-7 & HF-8 & HF-9 & HF-10 \\
\hline 采样位置 & $\begin{array}{l}\mathrm{N} 33^{\circ} 19.973^{\prime} \\
\mathrm{E} 113^{\circ} 04.533^{\prime}\end{array}$ & $\begin{array}{l}\mathrm{N} 33^{\circ} 20.002^{\prime} \\
\mathrm{E} 113^{\circ} 04.467\end{array}$ & $\begin{array}{l}\mathrm{N} 33^{\circ} 21.539^{\prime} \\
\mathrm{E} 113^{\circ} 01.243^{\prime}\end{array}$ & $\begin{array}{l}\mathrm{N} 33^{\circ} 21.683^{\prime} \\
\mathrm{E} 113^{\circ} 01.183^{\prime}\end{array}$ & $\begin{array}{l}\mathrm{N} 33^{\circ} 21.752^{\prime} \\
\mathrm{E} 113^{\circ} 01.180^{\prime}\end{array}$ & $\begin{array}{l}\mathrm{N} 33^{\circ} 21.655^{\prime} \\
\mathrm{E} 113^{\circ} 01.547^{\prime}\end{array}$ & $\begin{array}{l}\mathrm{N} 33^{\circ} 21.537^{\prime} \\
\mathrm{E} 113^{\circ} 01.676^{\prime}\end{array}$ & $\begin{array}{l}\mathrm{N} 33^{\circ} 21.449^{\prime} \\
\mathrm{E} 113^{\circ} 01.538^{\prime}\end{array}$ & $\begin{array}{l}\mathrm{N} 33^{\circ} 22.946^{\prime} \\
\mathrm{E} 113^{\circ} 00.755^{\prime}\end{array}$ & $\begin{array}{l}\mathrm{N} 33^{\circ} 22.867^{\prime} \\
\mathrm{E} 113^{\circ} 00.661^{\prime}\end{array}$ \\
\hline 岩性 & 霓辉正长岩 & 霓辉正长岩 & 霞石正长岩 & 霞石正长岩 & 霞石正长岩 & 霞石正长岩 & 霞石正长岩 & 霞石正长岩 & 霓辉正长岩 & 霞石正长岩 \\
\hline $\mathrm{Al}_{2} \mathrm{O}_{3}$ & 21.71 & 22.02 & 21.11 & 23.26 & 21.29 & 21.14 & 20.76 & 22.01 & 16.81 & 20.91 \\
\hline $\mathrm{CaO}$ & 0.35 & 0.04 & 1.89 & 1.56 & 1.66 & 2.13 & 2.48 & 1.99 & 1.09 & 1.53 \\
\hline $\mathrm{Fe}_{2} \mathrm{O}_{3}$ & 2.08 & 1.64 & 3.29 & 3.85 & 3.4 & 3.5 & 3.14 & 3.03 & 4.93 & 3.39 \\
\hline $\mathrm{K}_{2} \mathrm{O}$ & 13.92 & 14.66 & 8.13 & 6.51 & 7.09 & 7.23 & 5.55 & 6.89 & 7.17 & 6.22 \\
\hline $\mathrm{MgO}$ & 0.89 & 0.68 & 0.45 & 0.34 & 0.44 & 0.41 & 0.3 & 0.39 & 0.51 & 0.54 \\
\hline $\mathrm{MnO}$ & 0.02 & 0.02 & 0.26 & 0.45 & 0.26 & 0.25 & 0.29 & 0.21 & 0.19 & 0.19 \\
\hline $\mathrm{Na}_{2} \mathrm{O}$ & 0.1 & 0.02 & 5.48 & 8.4 & 6.85 & 5.37 & 7.15 & 5.95 & 5.02 & 7.18 \\
\hline $\mathrm{P}_{2} \mathrm{O}_{5}$ & 0.01 & 0 & 0.05 & 0.03 & 0.07 & 0.05 & 0.05 & 0.06 & 0.12 & 0.09 \\
\hline $\mathrm{SiO}_{2}$ & 56.64 & 58.71 & 57.53 & 54 & 57.03 & 57.86 & 58.19 & 57.39 & 62.12 & 58.68 \\
\hline $\mathrm{TiO}_{2}$ & 0.43 & 0.16 & 0.7 & 0.58 & 0.79 & 0.67 & 0.59 & 0.67 & 1.01 & 0.76 \\
\hline LOI & 4.67 & 1.59 & 0.84 & 0.59 & 0.39 & 0.81 & 0.72 & 1.32 & 0.84 & 0.44 \\
\hline 总量 & 100.82 & 99.54 & 99.73 & 99.57 & 99.27 & 99.42 & 99.22 & 99.91 & 99.81 & 99.93 \\
\hline $\mathrm{K}_{2} \mathrm{O}+\mathrm{Na}_{2} \mathrm{O}$ & 14.02 & 14.68 & 13.61 & 14.91 & 13.94 & 12.6 & 12.7 & 12.84 & 12.19 & 13.4 \\
\hline $\mathrm{Ti}$ & 2377 & 865.8 & 4218 & 3301 & 4923 & 3989 & 3447 & 4146 & 6053 & 4563 \\
\hline $\mathrm{Ga}$ & 34.04 & 29.47 & 32.94 & 43.07 & 32.34 & 30.07 & 28.45 & 33.88 & 33.15 & 28.82 \\
\hline $\mathrm{Rb}$ & 1055.4 & 1107.1 & 274.5 & 365.4 & 287.3 & 242.2 & 158.5 & 224.6 & 177.3 & 164.1 \\
\hline $\mathrm{Ba}$ & 8741.4 & 5213.7 & 202.3 & 38.16 & 153.4 & 111.5 & 104 & 87.59 & 751.4 & 524.6 \\
\hline Th & 30.2 & 9.303 & 26.53 & 40.41 & 32.7 & 23.29 & 35.64 & 8.116 & 14.27 & 22.08 \\
\hline $\mathrm{U}$ & 3.97 & 1.748 & 4.861 & 11.91 & 4.562 & 5.167 & 9.587 & 5.186 & 2.279 & 4.543 \\
\hline $\mathrm{Nb}$ & 192.4 & 63.12 & 263.7 & 454.9 & 263 & 219.5 & 324.5 & 278.9 & 131.7 & 179.1 \\
\hline $\mathrm{Ta}$ & 12.11 & 3.57 & 21.77 & 38.83 & 23.46 & 16.69 & 25.48 & 23.19 & 8.489 & 14.47 \\
\hline $\mathrm{Sr}$ & 184.9 & 100 & 338 & 125.7 & 299.3 & 409.3 & 389.9 & 285.9 & 38.67 & 443.6 \\
\hline $\mathrm{Hf}$ & 19.48 & 6.139 & 15.65 & 30.03 & 12.17 & 14.26 & 22.91 & 10.67 & 19.81 & 9.812 \\
\hline $\mathrm{Zr}$ & 994.2 & 284.9 & 693.1 & 1287.7 & 520 & 607.9 & 1019.1 & 438.9 & 920.5 & 441.2 \\
\hline $\mathrm{La}$ & 276.1 & 72.62 & 222.4 & 329.6 & 269 & 204.2 & 293.1 & 133.5 & 116.9 & 241.6 \\
\hline $\mathrm{Ce}$ & 488.2 & 112.7 & 455.1 & 626.6 & 542.4 & 396.5 & 567.4 & 296.6 & 234.3 & 453.8 \\
\hline $\operatorname{Pr}$ & 51.84 & 10.45 & 55.76 & 71.41 & 65.64 & 46.15 & 65.84 & 39.5 & 28.12 & 51.09 \\
\hline $\mathrm{Nd}$ & 123.2 & 25.46 & 159.6 & 192.7 & 194.6 & 131.3 & 182.6 & 120.6 & 91.96 & 146.2 \\
\hline $\mathrm{Sm}$ & 12.96 & 2.623 & 22.76 & 27.94 & 26.5 & 18.37 & 24.65 & 17.81 & 16.19 & 20.18 \\
\hline $\mathrm{Eu}$ & 1.740 & 0.246 & 2.926 & 2.123 & 3.457 & 2.424 & 2.786 & 2.272 & 1.954 & 3.132 \\
\hline $\mathrm{Gd}$ & 11.12 & 2.53 & 17.92 & 23.09 & 21.13 & 14.41 & 20.84 & 14.14 & 12.65 & 15.42 \\
\hline $\mathrm{Tb}$ & 1.076 & 0.246 & 2.278 & 3.275 & 2.597 & 1.753 & 2.696 & 2.225 & 1.929 & 1.816 \\
\hline Dy & 5.851 & 1.279 & 11.91 & 18.68 & 12.42 & 8.979 & 15.24 & 10.89 & 10.04 & 8.554 \\
\hline Ho & 1.100 & 0.274 & 2.212 & 3.848 & 2.309 & 1.641 & 3.215 & 2.286 & 1.961 & 1.55 \\
\hline $\mathrm{Er}$ & 3.434 & 0.839 & 6.475 & 11.76 & 6.013 & 4.55 & 9.861 & 6.149 & 5.547 & 4.177 \\
\hline $\mathrm{Tm}$ & 0.539 & 0.129 & 0.979 & 1.941 & 0.881 & 0.690 & 1.655 & 0.907 & 0.861 & 0.572 \\
\hline $\mathrm{Yb}$ & 3.515 & 0.859 & 6.394 & 12.41 & 5.029 & 4.244 & 10.86 & 5.531 & 5.663 & 3.493 \\
\hline $\mathrm{Lu}$ & 0.556 & 0.141 & 1.008 & 1.835 & 0.766 & 0.672 & 1.819 & 0.881 & 0.92 & 0.543 \\
\hline Y & 27.97 & 9.382 & 71.78 & 121.2 & 70.58 & 52.45 & 105.8 & 47.86 & 58.14 & 50.89 \\
\hline$\delta \mathrm{Eu}$ & 0.20 & 0.14 & 0.23 & 0.13 & 0.22 & 0.23 & 0.19 & 0.23 & 0.24 & 0.20 \\
\hline $\mathrm{T}_{\mathrm{Zr}}{ }^{\circ}{ }^{\circ} \mathrm{C}$ & 1044 & 896 & 967 & 1036 & 930 & 956 & 1009 & 920 & 1003 & 915 \\
\hline
\end{tabular}




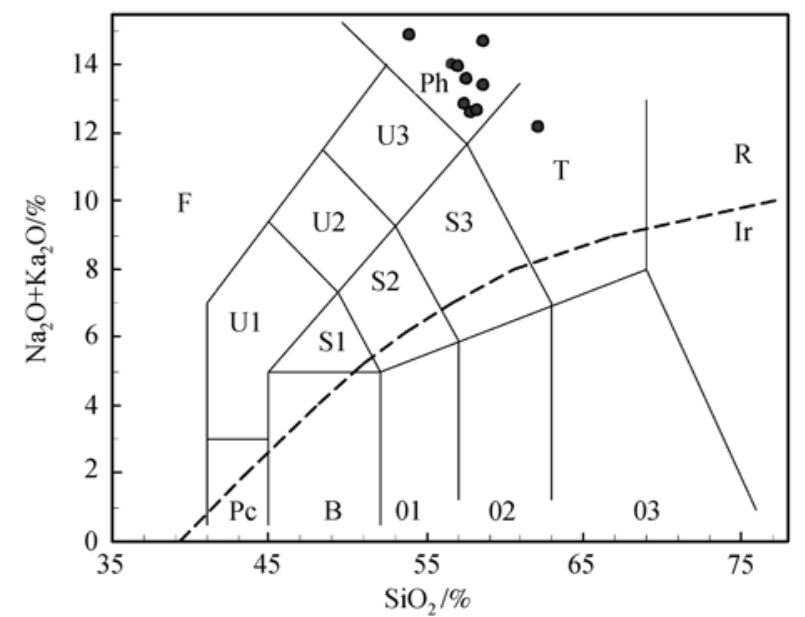

图 2 方城碱性正长岩 TAS 图解

岩石圈地幔小比例部分熔融, 在上升及侵位过程中 受到少量地壳物质混染.

根据锆石饱和温度计所估算的正长岩岩浆的温 度为 $915 \sim 1044^{\circ} \mathrm{C}^{[30]}$. 由于方城碱性正长岩中的锆石 为无色透明的短柱状且晶形完好的岩浆锆石, 未见 有残留锆石的出现. 因此, 锆石的饱和温度应为岩浆

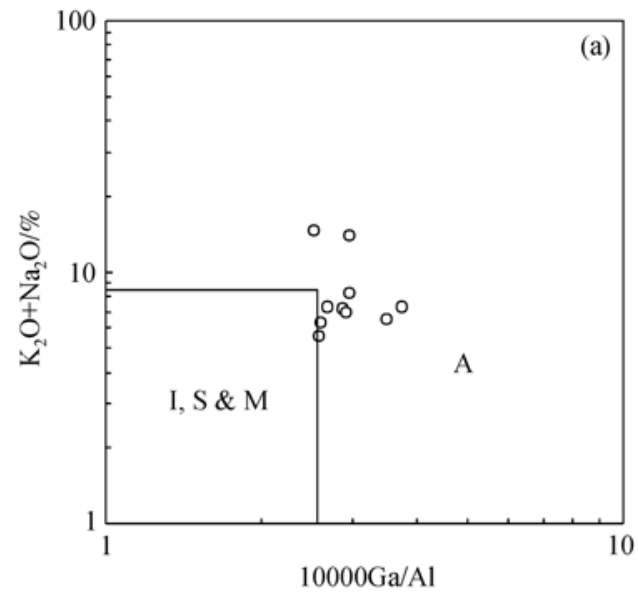

温度的最低估计值, 所以方城碱性正长岩岩浆形成 温度很高, 方城碱性正长岩的高温特征也支持其幔 源岩浆来源的推论.

\section{3 岩体的锆石 LA-ICPMS U-Pb 定年}

本次研究所分析的样品为双山岩体霓辉正长岩 (HF-9), 岩石主要矿物组成为微斜长石, 钠长石, 微 斜条纹长石, 少量霓辉石和霞石. 副矿物有锆石, 磷 灰石, 金红石, 磁铁矿等. 岩石具轻微的绢云母化蚀 变. 锆石为无色透明的短柱状晶体. 锆石阴极发光图 像研究在中国科学院广州地球化学研究所 JXA-8100 电子探针仪上完成(图 6). 阴极发光图像显示出清晰 的扇状振荡韵律环带结构, 为典型的岩浆成因锆石.

锆石 U-Pb 年龄测定在西北大学地质系大陆动力 学国家重点实验室完成. ICP-MS 为 Perkin Elmer/ SCIEX 公司带有动态反应池的四极杆 ICP-MS Elan6100DRC，参考物质为美国国家标准技术协会研制 的人工合成硅酸盐玻璃 NIST SRM610, 锆石 U-Pb 年 龄的测定采用国际标准锆石 91500 作为外标校正方 法, 以 $\mathrm{Si}$ 做内标, 测定锆石中的 $\mathrm{U}, \mathrm{Th}, \mathrm{Pb}$ 的含量. 详

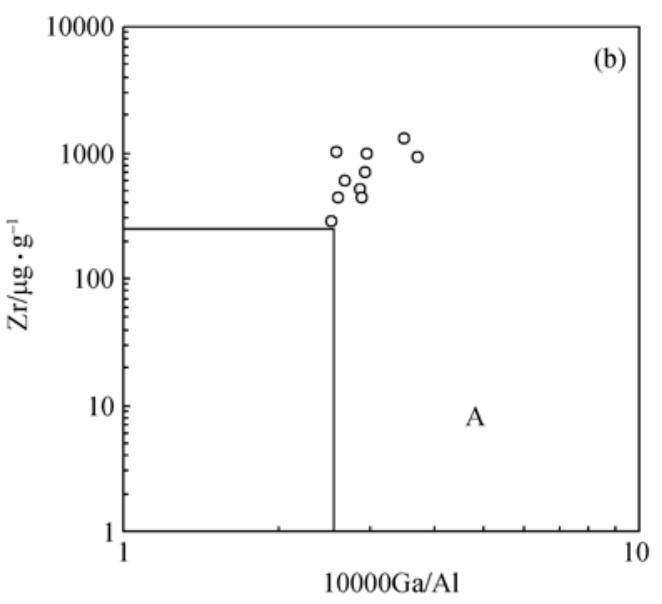

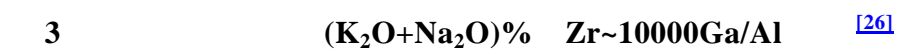

表 2 方城碱性正长岩 Sm-Nd 同位素组成

\begin{tabular}{lccccccc}
\hline 样品编号 & $\mathrm{Nd} / \mu \mathrm{g} \cdot \mathrm{g}^{-1}$ & $\mathrm{Sm} / \mu \mathrm{g} \cdot \mathrm{g}^{-1}$ & ${ }^{147} \mathrm{Sm} /{ }^{144} \mathrm{Nd}$ & ${ }^{143} \mathrm{Nd} /{ }^{144} \mathrm{Nd}$ & $2 \sigma$ & $\varepsilon_{\mathrm{Nd}}(t)$ & $T_{\mathrm{DM}} / \mathrm{Ma}$ \\
\hline $\mathrm{HF}-2$ & 25.46 & 2.623 & 0.06230 & 0.511697 & 0.000014 & -3.90 \\
HF-5 & 194.6 & 26.5 & 0.08235 & 0.511884 & 0.000013 & -2.41 & 1460 \\
HF-7 & 182.6 & 24.65 & 0.08163 & 0.511867 & 0.000011 & -2.66 & 1478 \\
HF-8 & 120.6 & 17.81 & 0.08930 & 0.511879 & 0.000009 & -3.26 & 1554 \\
HF-10 & 146.2 & 20.18 & 0.08347 & 0.511878 & 0.000009 & -2.66 & 1487 \\
塔 9 & $128]$ & 144.41 & 0.0721 & 0.511881 & 0.000029 & -1.37 & 1364 \\
双 $3^{[28]}$ & 16.9 & 113.21 & 0.0902 & 0.511876 & 0.000026 & -3.42 & 1569 \\
\hline
\end{tabular}




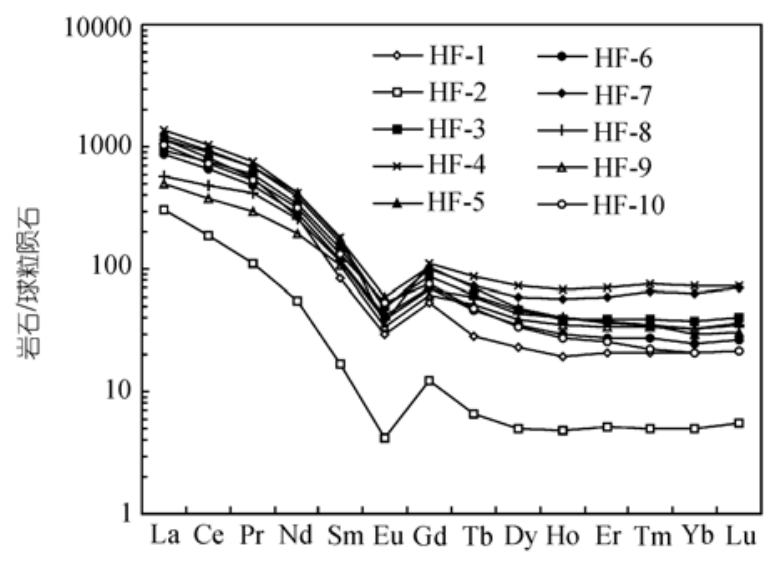

图 4 方城碱性正长岩稀土元素分布模式

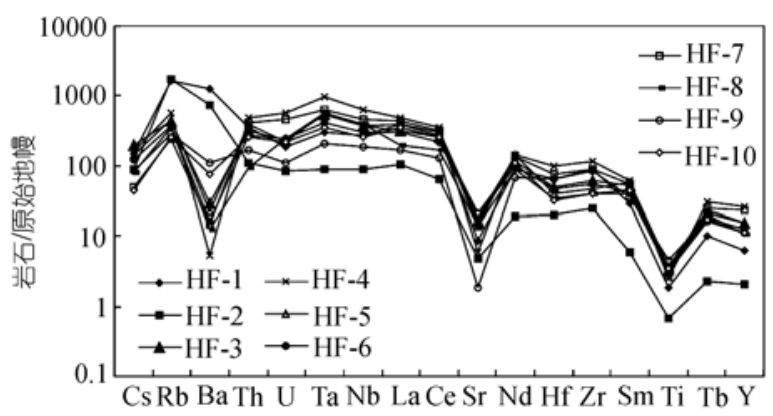

图 5 方城碱性正长岩原始地幔标准化微量元素蛛网图 [27]

细的分析流程及有关参数见袁洪林等人文 ${ }^{[31]}$.

对霓辉正长岩(HF-9)中的锆石进行了 30 个点的 测量. 锆石U-Pb的LA-ICPMS分析结果见表 3. Th含 量为 72.76 467.8 $\mu \mathrm{g} / \mathrm{g}$, U含量 $105.8 \sim 588.5 \mu \mathrm{g} / \mathrm{g}$, Th/U 比值变化范围 $0.69 \sim 1.58$, 具有岩浆成因锆石的 $T h / U$ 比值特征. ${ }^{206} \mathrm{~Pb} /{ }^{238} \mathrm{U}$ 年龄变化范围为 $759 \sim 866 \mathrm{Ma}$. 在 30 个测量点中有 2 个点 ${ }^{206} \mathrm{~Pb} /{ }^{238} \mathrm{U}$ 年龄明显偏低, 分 别为 769 和 $788 \mathrm{Ma}$, 其 $\mathrm{Th} / \mathrm{U}$ 比值明显低于其它测点
(分别为 0.69 和 0.70), 且其中一个测点 (HF- 9.01)U含 量及放射性成因铅的含量也非常高, 分别为 588.5 和 $359.4 \mu \mathrm{g} / \mathrm{g}$, 另有一个测点 ${ }^{206} \mathrm{~Pb} /{ }^{238} \mathrm{U}$ 年龄略有偏高 (866 Ma), 且 ${ }^{207} \mathrm{~Pb} /{ }^{206} \mathrm{~Pb},{ }^{207} \mathrm{~Pb} /{ }^{235} \mathrm{U},{ }^{208} \mathrm{~Pb} /{ }^{238} \mathrm{Th}$ 年龄 分别为 $1037,915,926 \mathrm{Ma}$, 具有显著的不一致性, 可 能为后期热液扰动的结果 ${ }^{[32]}$. 其余 27 个测点给出比 较一致的年龄结果(图 7). 剔除 3 个异常值后, 锆石 ${ }^{206} \mathrm{~Pb} /{ }^{238} \mathrm{U}$ 加权平均年龄为 $(844.3 \pm 1.6) \mathrm{Ma}, \mathrm{MSWD}=$ 0.86 . 该年龄应为正长岩岩浆结晶的年龄.

\section{4 岩体形成的时代、构造环境及其对 Rodinia 裂解过程的制约}

秦岭造山带现有的新元古代岩浆岩的精确同位 素定年资料(表 4)显示, 碰撞造山事件发生在 980 至 ９00 Ma之间； 890 至 860 Ma进入碰撞后伸展构造 演化阶段; 造山带内已知的板内岩浆岩年代仅有吐 雾 $\mathrm{A}$ 型花岗岩一例(锆石 $\mathrm{U}-\mathrm{Pb}$ 年龄为 711 725 $\mathrm{Ma}^{[4,17]}$ ), 缺少 860 至约 $710 \mathrm{Ma}$ 的岩浆活动记录. 相邻区域新 元古代岩浆岩有南秦岭的耀岭河群双峰式火山岩(锆 石U-Pb年龄 $\left.(808 \pm 6) \mathrm{Ma}^{[4]}\right)$, 扬子克拉通北缘的铁船 山组双峰式火山岩(玄武岩-流纹、英安岩; 锆石U-Pb 年龄为 $\left.(817 \pm 5) \mathrm{Ma}^{[5]}\right)$. 因此, 秦岭造山带的新元古 代碰撞造山构造演化过程缺少由碰撞后向板内非造 山拉张体制转化的可靠的岩浆活动的年代学控制.

霞石正长岩(及其对应的火山岩如碱玄岩, 响岩 及碳酸岩)与陆内裂谷系的联系已为众多研究所证实, 更是成为研究造山旋回的重要依据 ${ }^{[37 ~ 43]}$, 因此对研 究Rodinia裂解过程有着重要的意义. 到目前为止, 秦岭造山带除吐雾山碱性花岗岩 (711 725 Ma $\left.{ }^{[7,17]}\right)$ 外, 尚无其他新元古代的碱性岩、碱性花岗岩的报道.

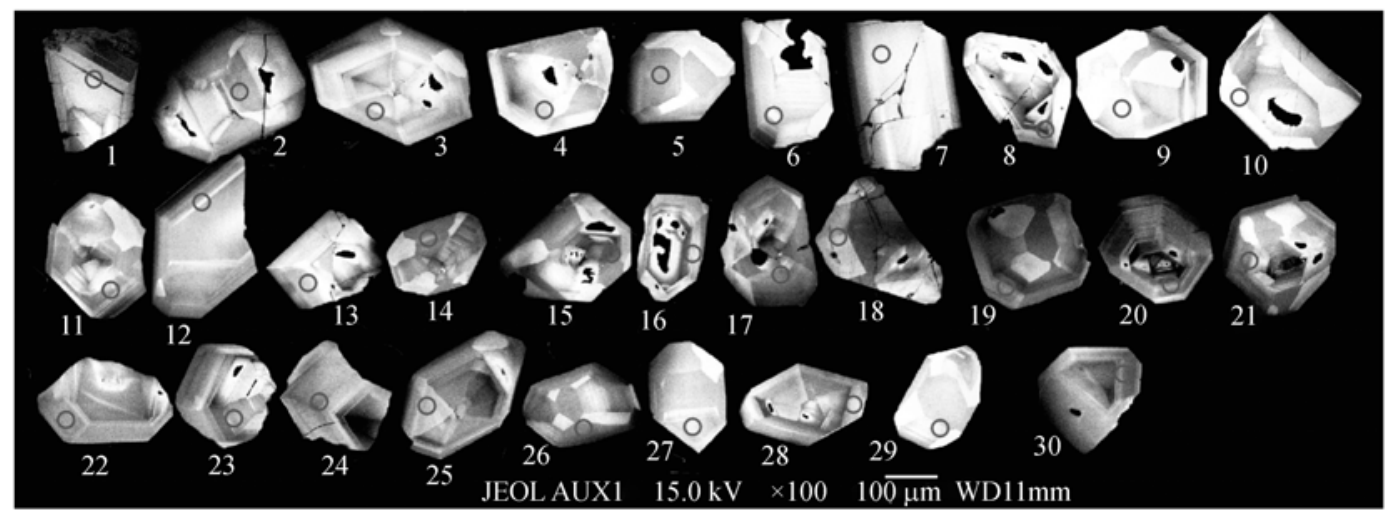

图 6 方城碱性正长岩(HF-9)锆石阴极发光及 LA-ICPMS 分析点位置 
表 3 方城霞石正长岩锆石 LA-ICPMS 分析结果

\begin{tabular}{|c|c|c|c|c|c|c|c|c|c|c|c|c|c|c|c|c|c|c|c|c|}
\hline \multirow{3}{*}{ 样号 } & \multirow{2}{*}{\multicolumn{3}{|c|}{ 含量/ $\mu \mathrm{g} \cdot \mathrm{g}^{-1}$}} & \multirow{3}{*}{$\mathrm{Th} / \mathrm{U}$} & \multicolumn{8}{|c|}{ 同位素比值 } & \multicolumn{8}{|c|}{ 年龄/Ma } \\
\hline & & & & & \multicolumn{2}{|c|}{${ }^{207} \mathrm{~Pb} /{ }^{206} \mathrm{~Pb}$} & \multicolumn{2}{|c|}{${ }^{207} \mathrm{~Pb} /{ }^{235} \mathrm{U}$} & \multicolumn{2}{|c|}{${ }^{206} \mathrm{~Pb} /{ }^{238} \mathrm{U}$} & \multicolumn{2}{|c|}{${ }^{208} \mathrm{~Pb} /{ }^{232} \mathrm{Th}$} & \multicolumn{2}{|c|}{${ }^{207} \mathrm{~Pb} /{ }^{206} \mathrm{~Pb}$} & \multicolumn{2}{|c|}{${ }^{207} \mathrm{~Pb} /{ }^{235} \mathrm{U}$} & \multicolumn{2}{|c|}{${ }^{206} \mathrm{~Pb} /{ }^{238} \mathrm{U}$} & \multicolumn{2}{|c|}{${ }^{208} \mathrm{~Pb} /{ }^{232} \mathrm{Th}$} \\
\hline & $\mathrm{Pb}_{\mathrm{rad}}$ & ${ }^{232} \mathrm{Th}$ & ${ }^{238} \mathrm{U}$ & & 比值 & $1 \sigma$ & 比值 & $1 \sigma$ & 比值 & $1 \sigma$ & 比值 & $1 \sigma$ & 年龄 & $1 \sigma$ & 年龄 & $\overline{1 \sigma}$ & 年龄 & $1 \sigma$ & 年龄 & $1 \sigma$ \\
\hline HF-9.01 & 359.4 & 410.5 & 588.5 & 0.70 & 0.06681 & 0.00082 & 1.1971 & 0.01054 & 0.12995 & 0.00072 & 0.0445 & 0.00027 & 832 & 10 & 799 & 5 & 788 & 4 & 880 & 5 \\
\hline HF-9.02 & 116.2 & 149.4 & 173.4 & 0.86 & 0.06749 & 0.00083 & 1.30813 & 0.0115 & 0.14057 & 0.00078 & 0.04433 & 0.00026 & 853 & 10 & 849 & 5 & 848 & 4 & 877 & 5 \\
\hline HF-9.03 & 102.3 & 131.5 & 152.8 & 0.86 & 0.06636 & 0.00084 & 1.28229 & 0.0119 & 0.14013 & 0.00078 & 0.04503 & 0.00027 & 818 & 11 & 838 & 5 & 845 & 4 & 890 & 5 \\
\hline HF-9.04 & 133.4 & 215.2 & 185.6 & 1.16 & 0.07383 & 0.00091 & 1.46327 & 0.01291 & 0.14373 & 0.0008 & 0.04689 & 0.00026 & 1037 & 9 & 915 & 5 & 866 & 5 & 926 & 5 \\
\hline HF-9.05 & 189.2 & 206.4 & 286.2 & 0.72 & 0.06782 & 0.00079 & 1.31338 & 0.01038 & 0.14043 & 0.00076 & 0.04471 & 0.00025 & 863 & 8 & 852 & 5 & 847 & 4 & 884 & 5 \\
\hline HF-9.06 & 161.9 & 228.3 & 237.4 & 0.96 & 0.06674 & 0.00079 & 1.29645 & 0.01051 & 0.14086 & 0.00076 & 0.04403 & 0.00024 & 830 & 9 & 844 & 5 & 850 & 4 & 871 & 5 \\
\hline HF-9.07 & 104.3 & 143.1 & 152.8 & 0.94 & 0.06784 & 0.00088 & 1.31431 & 0.01286 & 0.1405 & 0.0008 & 0.04557 & 0.00028 & 864 & 11 & 852 & 6 & 847 & 5 & 901 & 5 \\
\hline HF-9.08 & 214.9 & 467.8 & 296.3 & 1.58 & 0.06631 & 0.00078 & 1.28145 & 0.0104 & 0.14015 & 0.00076 & 0.04241 & 0.00021 & 816 & 9 & 837 & 5 & 846 & 4 & 840 & 4 \\
\hline HF-9.09 & 118.7 & 200.0 & 169.2 & 1.18 & 0.06718 & 0.00087 & 1.30114 & 0.01261 & 0.14046 & 0.00079 & 0.04451 & 0.00025 & 843 & 11 & 846 & 6 & 847 & 4 & 880 & 5 \\
\hline HF-9.10 & 77.39 & 93.02 & 116.0 & 0.80 & 0.06951 & 0.00105 & 1.33046 & 0.01649 & 0.13882 & 0.00086 & 0.04537 & 0.00035 & 914 & 15 & 859 & 7 & 838 & 5 & 897 & 7 \\
\hline HF-9.11 & 151.7 & 203.6 & 222.7 & 0.91 & 0.06799 & 0.00083 & 1.31478 & 0.0114 & 0.14023 & 0.00077 & 0.04413 & 0.00025 & 868 & 9 & 852 & 5 & 846 & 4 & 873 & 5 \\
\hline HF-9.12 & 126.8 & 171.0 & 188.1 & 0.91 & 0.06790 & 0.00087 & 1.30246 & 0.01235 & 0.13911 & 0.00078 & 0.04274 & 0.00026 & 866 & 11 & 847 & 5 & 840 & 4 & 846 & 5 \\
\hline HF-9.13 & 134.5 & 194.8 & 196.7 & 0.99 & 0.06630 & 0.00086 & 1.2759 & 0.01233 & 0.13956 & 0.00079 & 0.04355 & 0.00026 & 816 & 11 & 835 & 6 & 842 & 4 & 862 & 5 \\
\hline HF-9.14 & 126.3 & 189.8 & 182.5 & 1.04 & 0.06639 & 0.00084 & 1.28518 & 0.0119 & 0.14038 & 0.00078 & 0.04326 & 0.00025 & 819 & 10 & 839 & 5 & 847 & 4 & 856 & 5 \\
\hline HF-9.15 & 141.5 & 223.0 & 205.2 & 1.09 & 0.06665 & 0.00085 & 1.27512 & 0.01201 & 0.13875 & 0.00078 & 0.04325 & 0.00025 & 827 & 11 & 835 & 5 & 838 & 4 & 856 & 5 \\
\hline HF-9.16 & 123.7 & 191.5 & 179.4 & 1.07 & 0.06750 & 0.00091 & 1.28916 & 0.01338 & 0.1385 & 0.0008 & 0.04320 & 0.00027 & 853 & 12 & 841 & 6 & 836 & 5 & 855 & 5 \\
\hline HF-9.17 & 101.1 & 122.2 & 149.7 & 0.82 & 0.06731 & 0.00088 & 1.29315 & 0.01268 & 0.13933 & 0.00079 & 0.04422 & 0.00028 & 847 & 11 & 843 & 6 & 841 & 4 & 875 & 5 \\
\hline HF-9.18 & 63.59 & 72.76 & 105.8 & 0.69 & 0.06900 & 0.00101 & 1.18886 & 0.01397 & 0.12495 & 0.00075 & 0.04234 & 0.00032 & 899 & 14 & 795 & 6 & 759 & 4 & 838 & 6 \\
\hline HF-9.19 & 84.23 & 96.03 & 124.2 & 0.77 & 0.06832 & 0.00097 & 1.31787 & 0.01492 & 0.13989 & 0.00083 & 0.04560 & 0.00032 & 878 & 14 & 854 & 7 & 844 & 5 & 901 & 6 \\
\hline HF-9.20 & 126.5 & 180.0 & 182.1 & 0.99 & 0.06714 & 0.00084 & 1.29812 & 0.01181 & 0.14021 & 0.00078 & 0.04371 & 0.00025 & 842 & 10 & 845 & 5 & 846 & 4 & 865 & 5 \\
\hline HF-9.21 & 122.6 & 161.2 & 177.0 & 0.91 & 0.06693 & 0.00089 & 1.29568 & 0.01325 & 0.14038 & 0.00081 & 0.04528 & 0.00028 & 836 & 12 & 844 & 6 & 847 & 5 & 895 & 5 \\
\hline HF-9.22 & 132.3 & 158.7 & 193.7 & 0.82 & 0.06665 & 0.00085 & 1.28359 & 0.01216 & 0.13967 & 0.00079 & 0.04541 & 0.00028 & 827 & 11 & 838 & 5 & 843 & 4 & 898 & 5 \\
\hline HF-9.23 & 150.3 & 231.1 & 211.3 & 1.09 & 0.06787 & 0.00085 & 1.31445 & 0.01196 & 0.14046 & 0.00078 & 0.04542 & 0.00025 & 865 & 10 & 852 & 5 & 847 & 4 & 898 & 5 \\
\hline HF-9.24 & 215.6 & 288.0 & 309.7 & 0.93 & 0.06788 & 0.00077 & 1.31262 & 0.00985 & 0.14025 & 0.00075 & 0.04465 & 0.00023 & 865 & 8 & 851 & 4 & 846 & 4 & 883 & 4 \\
\hline HF-9.25 & 97.97 & 112.1 & 142.9 & 0.78 & 0.06789 & 0.00088 & 1.31341 & 0.01278 & 0.14029 & 0.00079 & 0.04534 & 0.00029 & 865 & 11 & 852 & 6 & 846 & 4 & 896 & 6 \\
\hline HF-9.26 & 141.0 & 197.8 & 199.7 & 0.99 & 0.06966 & 0.00085 & 1.34744 & 0.01175 & 0.14028 & 0.00077 & 0.04525 & 0.00025 & 918 & 9 & 866 & 5 & 846 & 4 & 895 & 5 \\
\hline HF-9.27 & 107.9 & 135.7 & 155.0 & 0.88 & 0.06805 & 0.00088 & 1.31865 & 0.01267 & 0.14052 & 0.00079 & 0.04504 & 0.00027 & 870 & 11 & 854 & 6 & 848 & 4 & 890 & 5 \\
\hline HF-9.28 & 145.6 & 233.5 & 205.8 & 1.13 & 0.06801 & 0.00084 & 1.30246 & 0.01159 & 0.13888 & 0.00077 & 0.04281 & 0.00024 & 869 & 10 & 847 & 5 & 838 & 4 & 847 & 5 \\
\hline HF-9.29 & 111.7 & 149.5 & 159.4 & 0.94 & 0.06913 & 0.00087 & 1.33439 & 0.01235 & 0.13999 & 0.00078 & 0.04439 & 0.00026 & 903 & 10 & 861 & 5 & 845 & 4 & 878 & 5 \\
\hline HF-9.30 & 109.5 & 138.8 & 159.8 & 0.87 & 0.06848 & 0.00102 & 1.30561 & 0.01572 & 0.13827 & 0.00084 & 0.04303 & 0.00031 & 883 & 15 & 848 & 7 & 835 & 5 & 852 & 6 \\
\hline
\end{tabular}




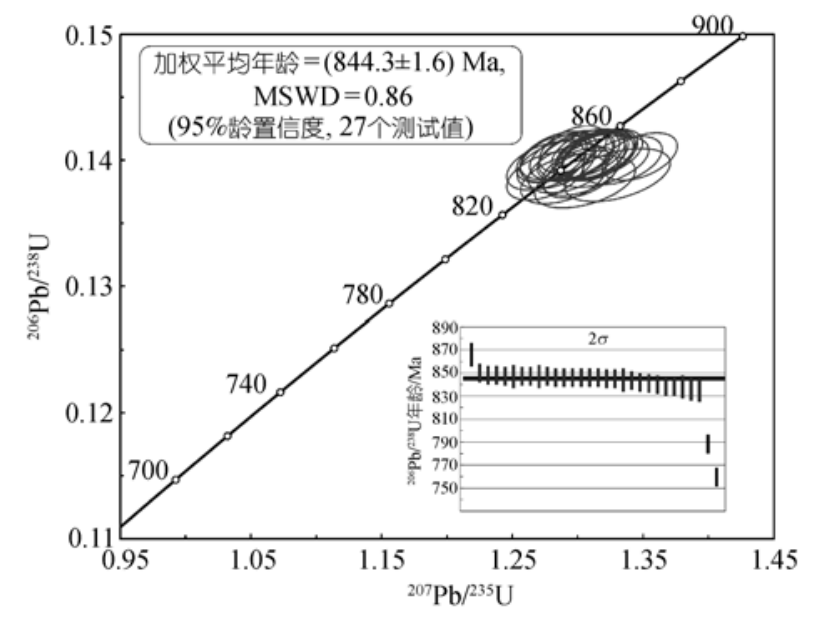

图 7 方城碱性正长岩(HF-9)锆石 U-Pb 谐和图及 ${ }^{206} \mathrm{~Pb} /{ }^{238} \mathrm{U}$ 年龄谱图

前人 [21.28]曾试图用 Rb-Sr等时线法对方城碱性正 长岩进行同位素定年, 然而由于碱性正长岩本身在 形成和演化过程中未必达到 $\mathrm{Rb}-\mathrm{Sr}$ 同位素体系的平衡, 加上后期热液蚀变作用的扰动, 很难实现精确的同 位素定年. 邱家哼等人 ${ }^{[21]}$ 对绢云母化碱性长石正长 岩、角闪云霞正长岩所分析的 $\mathrm{Rb}-\mathrm{Sr}$ 等时线年龄及初 始值分别为: $(1452 \pm 15) \mathrm{Ma},\left({ }^{87} \mathrm{Sr} /{ }^{86} \mathrm{Sr}\right)_{i}=0.6988$; $(786 \pm 15) \mathrm{Ma},\left({ }^{87} \mathrm{Sr}{ }^{86} \mathrm{Sr}\right)_{i}=0.7083$. 张正伟等人 ${ }^{[28]}$ 报 道的塔山正长岩的 Rb-Sr等时线年龄及初始值分别为 $298 \mathrm{Ma},\left({ }^{87} \mathrm{Sr} /{ }^{86} \mathrm{Sr}\right)_{i}=0.7332$. 这些数据差别很大,
可靠程度较低. 由于方城碱性正长岩中的锆石为无 色透明且具有清晰振荡环带的岩浆锆石, 所以锆石 $\mathrm{LA}-\mathrm{ICPMS} \mathrm{U-Pb}$ 年龄 $((844.3 \pm 1.6) \mathrm{Ma}, \mathrm{MSWD}=0.86)$ 为岩体的结晶年龄.

方城碱性正长岩形成于新元古代早期((844.3 \pm 1.6) $\mathrm{Ma})$ 、具有很高的岩浆温度 $\left(915 \sim 1044^{\circ} \mathrm{C}\right)$ 、较低 的 $\mathrm{Nd}$ 模式年龄 $(1364 \sim 1569 \mathrm{Ma})$ 和较高的 $\varepsilon_{\mathrm{Nd}}(t)$ $(-1.37 \sim-3.90)$ 值、具有板内裂谷环境岩浆岩的微量元 素地球化学特征, 在Eby ${ }^{[44]}$ 所提出的 $\mathrm{A}$ 型花岗岩构造 环境判别图(Nb-Y-Ce和 Nb-Y-3Ga)上均落入 $\mathrm{A}_{1}$ 型区内 (图 8), 表明方城碱性正长岩形成于(板内)非造山构 造环境, 可能与加厚地壳-岩石圈拆沉作用所引起的 地幔上涌有关. 因此, 秦岭造山带新元古代的造山作 用极有可能在 $844 \mathrm{Ma}$ 已完成了由碰撞后向非造山板 内拉张构造环境的转化.

华南新元古代岩浆岩成岩机制和地球动力学背
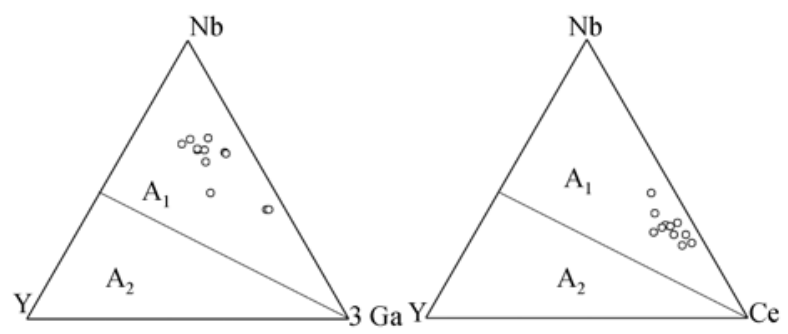

图 8 方城碱性正长岩Ga-Y-Nb, Ce-Y-Nb构造 环境判别图 [44]

表 4 秦岭造山带新元古代岩浆活动记录

\begin{tabular}{|c|c|c|c|c|c|}
\hline 阶段 & 样品名称 & 采样地点 & 侵入时代/Ma & 测年方法 & 资料来源 \\
\hline \multirow{10}{*}{ 碰撞造山期 } & 花岗质片麻岩 & 西秦岭新阳 & $981 \pm 5$ & LA-ICPMS & [33] \\
\hline & 片麻状花岗岩 & 北秦岭牛角山 & $955 \pm 13$ & SHRIMP & [34] \\
\hline & 花岗片麻岩 & 西秦岭元龙 & $924.2 \pm 2.7$ & LA-ICPMS & [35] \\
\hline & 花岗闪长质片麻岩 & 户县西涝峪 & $955.5 \pm 8.4$ & TIMS & \multirow{7}{*}{ [4] } \\
\hline & 花岗片麻岩 & 卢氏狮子坪 & $954.6 \pm 5.1$ & TIMS & \\
\hline & 花岗片麻岩 & 西狭德河 & $964 \pm 5.2$ & TIMS & \\
\hline & & 四峡㯖河 & $943 \pm 18$ & SHRIMP & \\
\hline & 花岗片麻岩 & 西峡根寨 & $914 \pm 10$ & SHRIMP & \\
\hline & \multirow{2}{*}{ 花岗片麻岩 } & \multirow{2}{*}{ 太白官山 } & $911 \pm 18$ & SHRIMP & \\
\hline & & & $863 \pm 17$ & TIMS & \\
\hline \multirow{2}{*}{ 碰撞后 } & 花岗片麻状岩 & 蔡凹花岗岩 & $889 \pm 10$ & LA-ICPMS & [16] \\
\hline & 花岗片麻状岩 & 两河口 & $863 \pm 17$ & TIMS & [36] \\
\hline \multirow{6}{*}{$\begin{array}{l}\text { 板内-非造山 } \\
\text { 环境 }\end{array}$} & 碱性正长岩 & 方城双山 & $844.3 \pm 1.6$ & LA-ICPMS & 本文 \\
\hline & \multirow{2}{*}{ 碱性花岗岩 } & \multirow{2}{*}{ 南阳吐雾山 } & $711 \pm 11$ & SHRIMP & [7] \\
\hline & & & $725 \pm 39$ & TIMS & {$[17]$} \\
\hline & 花岗闪长岩 & 河南淅川老君殿 & $711 \pm 11$ & LA-ICPMS & \multirow{2}{*}{ [4] } \\
\hline & 耀岭河群酸性火山岩 & 南秦岭 & $808 \pm 6$ & TIMS & \\
\hline & 铁船山组流纹岩 & 扬子北缘 & $817 \pm 5$ & TIMS & [5] \\
\hline
\end{tabular}


景及其与Rodinia超大陆聚合-裂解的关系是近年来国 内外地学界关注的热点之一. 目前对华南新元古代岩 浆岩的成因存在地幔柱岩浆活动 [45 58]、岛弧岩浆作 用 ${ }^{[49]}$ 及板块-裂谷岩浆活动产物 ${ }^{[50]} 3$ 种不同的模型. “地幔柱” 模式认为 $>860 \mathrm{Ma}$ (多数为 $\geq 900 \mathrm{Ma}$ ) 的岩浆 岩的形成与Rodinia超大陆聚合的造山过程有关, 而 830 740 Ma 的岩浆岩的形成则与Rodinia裂解过程 中的地幔柱活动有关, 为非造山阶段岩浆活动的产 物 ${ }^{[24,46,51,52]}$. 其中, 川西南关刀山花岗闪长岩(锆石 SHRIMP U-Pb年龄 $(857 \pm 13) \mathrm{Ma})$ 被认为是典型的 I 型花岗岩, 是由中元古代末-新元古代初岛弧低钾拉 斑玄武质岩石部分熔融形成的板内非造山岩浆活动 的产物 ${ }^{[53]}$. 扬子地块西缘沿康定裂谷分布的新元古 代(830 740 Ma)岩浆岩、苏雄双峰式火山岩( 800 Ma) 亦可能是与地幔柱活动有关的板内岩浆作用的产物 [46,48,54,55]. “岛弧”模式则认为大多数中-晚元古代岩浆 岩分布在扬子地块的活动大陆边缘, 是同时期洋壳 俯冲过程中岛弧岩浆活动产物, 华南自 $>860$ 至 $\sim 750 \mathrm{Ma}$ 一直处于造山阶段 ${ }^{[49,56 ~ 58]}$. 扬子地块周边新 元古代镁铁质-玄武质火山岩微量元素组成的岛弧特 性是“岛弧”模式的最重要的依据 ${ }^{[49,56,57,59,60]}$. 而“板块裂谷”模式则认为, 华南新元古代 830 800 $\mathrm{Ma}$ 和 780 750 Ma两期岩浆活动是超大陆从裂谷构造发展 到裂解过程的产物, 其动力学机制是岩石圈拉张所 引起的构造垮塌深熔和裂谷再造; 在物质来源上具 有“就地取材”特点: 古老与新生岩石圈地幔、古老与 新生大陆地壳都可能发生部分熔融, 结果形成不同 成分和性质的岩浆岩 $[50,61]$.

值得注意的是, 岛弧火山岩具有典型的 $\mathrm{Nb}, \mathrm{Ta}$, $\mathrm{Ti}$ 等高场强元素亏损特点, 但并不等于具有高场强 元素亏损特征的火山岩就必然形成于岛弧环境. 花 岗岩类的地球化学特征主要受其源区物质组成及岩 浆演化过程的制约，仅仅根据花岗质岩石地球化学 特征所作的构造环境判别可能会导致完全错误的结 论 ${ }^{[62,63]}$. 由此可见, 区内新元古代花岗岩类及玄武质 岩浆岩地球化学特征所反映的构造环境的不确定性 成为研究华南Rodina大陆碰撞拼合与裂解过程的重
要疑障, 而东秦岭方城碱性正长岩的研究为这个问 题的解决提供了新的契机.

方城碱性正长岩锆石U-Pb年龄的精确定年表明, 秦岭造山带由碰撞造山向后造山、非造山阶段的转换 时代比原来认识( $825 \mathrm{Ma})$ 的要早至少 $20 \mathrm{Ma}$, 在 844 Ma左右已经进入后造山-非造山演化阶段. 同时秦岭 造山带松树沟超基性岩辉石巨晶 ${ }^{40} \mathrm{Ar}^{3}{ }^{39} \mathrm{Ar}$ 年龄 (848.2 土4) $\mathrm{Ma}^{[64]}$ 所代表的热事件与方城碱性正长岩形成的 年代相近, 也为 $844 \mathrm{Ma}$ 左右存在地幔上涌过程提供 了间接的支持. 川西刀关山岩体的精确定年(锆石 SHRIMP U-Pb年龄 $(857 \pm 13) \mathrm{Ma})$ 及其板内非造山构 造环境的厘定也为华南Rodinia古陆构造格局转换的 时限提供了有力的支持. 另外, 根据 $\mathrm{Wu}$ 等人 ${ }^{[65]}$ 对扬 子克拉通东南缘皖南新元古代 $S$ 型花岗闪长岩的同位 素年代学和地球化学研究, 中元古代晚期形成的新 生地壳在 $(900 \pm 20) \mathrm{Ma}$ 弧陆碰撞和 825 Ma构造跨塌 过程中发生再造. 这指示, 华南构造体制从压缩转换 为拉张的时间出现在 870 830 Ma之间. 因此, 本文 对方城正长岩锆石 $\mathrm{U}-\mathrm{Pb}$ 年龄结果说明，华南Rodinia 超大陆碰撞造山作用结束并进入非造山拉张演化阶 段发生在 $844 \mathrm{Ma}$ 左右.

\section{5 结论}

方城碱性正长岩具有典型的碱性岩的低硅、富碱 的特点 $\left(\mathrm{SiO}_{2}=54 \% \sim 62 \%, \mathrm{~K}_{2} \mathrm{O}+\mathrm{Na}_{2} \mathrm{O}=12 \% \sim 15 \%\right)$, 矿物组成包括霞石和碱性暗色矿物霓辉石. 微量元 素和 $\mathrm{Nd}$ 同位素组成表明, 其形成于板内非造山环 境、且形成的温度较高 $\left(915 \sim 1044^{\circ} \mathrm{C}\right)$, 主要为上地幔 小比例部分熔融的产物、在上升或侵位过程中发生少 量地壳物质的混染. 锆石 U-Pb 的 LA-ICPMS 测定表 明, 岩体形成于 $(844.3 \pm 1.6) \mathrm{Ma}$, 为秦岭造山带及华 南地区已知形成时代最早的新元古代碱性岩. 秦岭 造山带的地球动力学背景由碰撞后向后造山-非造山 的转换应不晚于 $844 \mathrm{Ma}$. 结合扬子克拉通内部及周 边新元古代非造山岩浆岩活动的研究成果, 华南 Rodinia超大陆完成碰撞聚合并在 $844 \mathrm{Ma}$ 左右转入板 内非造山拉张演化阶段.

致谢野外工作期间得到了河南省国土资源科学研究院卢欣祥教授、原振雷博士的帮助, 室内分析期间得到了刘颖、 涂湘林、资锋和唐功建等的帮助, 审稿专家对本文的初稿提出了建设性的修改意见, 在此一并表示感谢. 
1 Meng Q R, Zhang G W. Geologic framework and tectonic evolution of the Qinling orogen, central China. Tectonophysics, 2000, 323: 183-196[doi]

2 张国伟, 张本仁, 袁学诚, 等. 秦岭造山带与大陆动力学. 北京: 科学出版社, 2001. 885

3 Xue F, Lerch M F, Kröner A, et al. Tectonic evolution of the East Qinling Mountains, China, in the Phanerozoic: A review and new tectonic model. Tectonophysics, 1996, 253: 271-284[doi] 陆松年，李怀坤，陈志宏，等. 秦岭中-新元古代地质演化及对 RODINIA 超级大陆事件的响应. 北京: 地质出版社, 2003.194 Ling W, Gao S, Zhang B, et al. Neoproterozoic tectonic evolution of the northwestern Yangtze Craton, South China: implications for amalgamation and breakup of the Rodinia Supercontinent. Precambrian Res, 2003, 122: 111-140[doi]

6 Wang T, Wang X, Zhang G, et al. Remnants of a Neoproterozoic collisional orogenic belt in the core of the Phanerozoic Qinling orogenic belt (China). Gondwana Res, 2003, 6(4): 699-710 [doi]

7 Chen Z, Lu S, Li H, et al. Constraining the role of the Qinling orogen in the assembly and break-up of Rodinia: Tectonic implications for Neoproterozoic granite occurrences. J Asian Earth Sci, 2006, 28: 99-115[doi]

8 曾建元, 杨宏仪, 万渝生, 等. 北祁连山变质杂岩中新元古代( 775 Ma) 岩浆活动纪录的发现: 来自 SHRIMP 锆石 U-Pb 定年 的证据. 科学通报, 2006, 51(5): 575-581

9 Zheng Y F, Wu Y B, Chen F K, et al. Zircon U-Pb and oxygen isotope evidence for a large-scale ${ }^{18} \mathrm{O}$ depletion event in igneous rocks during the Neoproterozoic. Geochim Cosmochim Acta, 2004, 68: 4145-4165[doi]

10 刘会涁, 裴先治, 丁仨平, 等. 西秦岭天水市元龙地区新元古代花岗质片麻岩锆石 LA-ICP-MS U-Pb 定年及其地质意义. 地 质通报, 2006, 25(11): 1315-1320

11 董云鹏，周鼎武，张国伟。东秦岭松树沟超镁铁质岩侵位机制及其构造演化. 地质科学, 1997, 32(2): 173-180

12 李曙光, 陈移之, 张国伟, 等. 一个距今 10 年侵位的阿尔卑斯型橄榄岩体: 北秦岭晚元古代板块体制的证据. 地质论评, 1991, 37(3): 235-242

13 刘良, 周鼎武, 王焰, 等. 东秦岭杂岩中的长英质高压麻粒岩及其地质意义初探. 中国科学 D 辑: 地球科学, 1996, 26(增刊): $56-63$

14 裴先治, 李厚民, 李国光. 北秦岭商南花岗岩体地球化学特征及其形成的构造环境. 西安地质学院学报, 1996, 18(3): 29一-35

15 裴先治, 王涛, 丁仨平, 等. 东秦岭商丹带北侧新元古代埃达克质花岗岩及其地质意义. 中国地质, 2003, 30(4): 372-381

16 张成立, 刘良, 张国伟, 等。北秦岭新元古代后碰撞花岗岩的确定及其构造意义. 地学前缘, 2004, 11(3): 33-42

17 卢欣祥, 董有, 尉向东, 等. 东秦岭吐雾山 A 型花岗岩的时代及其构造意义. 科学通报, 1999, 44(9): 975一 978

18 徐学义, 夏祖春, 夏林圻. 碧口群火山旋回及其地质构造意义. 地质通报, 2002, 21(8-9): 478一 485

19 Yan Q R, Hanson A D, Wang Z Q, et al. Neoproterozoic Subduction and Rifting on the Northern Margin of the Yangtze Plate, China: Implications for Rodinia Reconstruction. Int Geol Rev, 2004, 46: 817-832[doi]

20 陆松年, 陈志宏, 李怀坤, 等. 秦岭造山带中两条新元古代岩浆岩带. 地质学报, 2005, 79(2): 165-173

21 邱家骧, 等. 秦巴碱性岩. 北京: 地质出版社, 1993. 183

22 蒋千清, 周洪瑞, 王自强。豫西栾川地区栾川群的层序、沉积环境及其构造古地理意义. 现代地质, 1994, 8(4): 430一-440

张正伟，周玲棣，朱炳泉，等。东秦岭北部富碱侵入岩的主要矿物组成. 矿物学报, 2002, 22(1): 67一74

Li X H. Geochemistry of the Longsheng ophiolite from the southern margin of Yangtze Craton, SE China. Geochem J, 1997, 31: 323-337

Li X H, Li Z X, Zhou H, et al. U-Pb zircon geochronology, geochemistry and Nd isotopic study of Neoproterozoic bimodal volcanic rocks in the Kangdian Rift of South China: Implications for the initial rifting of Rodinia. Precambrian Res, 2002, 113: 135-154[doi]

Whalen J B, Currie K L, Chappell B W. A-type granites: Geochemical characteristics, discrimination and petrogenesis. Contrib Mineral Petrol, 1987, 95: 407-419[10i]

Sun S S, McDonough W F. Chemical and isotopic systematics of oceanic basalts: Implications for mantle composition and processes. In: Saunders A D, Norry M J, eds. Magmatism in the Ocean Basins. London: Geological Society of London, 1989. 313-345 Watson E B, Harrison T M. Zircon saturation revisited; temperature and composition effects in a variety of crustal magma types. Earth Planet Sci Lett, 1983, 64(2): 295-304 [doi]

31 袁洪林, 吴福元, 高山, 等. 东北地区新生代侵入体的锆石激光探针 U-Pb 年龄测定与稀土元素成分分析. 科学通报, 2003 , 48(14): 1511-1520

32 Breeding C M, Ague J J, Grove M, et al. Isotopic and chemical alteration of zircon by metamorphic fluids: U-Pb age depth-profiling of zircon crystal from Barrow's garnet zone, northwest Scotland. Am Mineral, 2004, 89: 1067-1077

33 丁仨平, 裴先治, 刘会涁, 等. 西秦岭天水地区新阳新元古代花岗质片麻岩的锆石 LA-ICP-MS 定年及其地质意义. 中国地质, 2006, 33(6) : 1217-1225

34 王涛, 张宗清, 王晓霞, 等. 秦岭造山带核部新元古代碰撞变形及其时代一一强变形同碰撞花岗岩与弱变形脉体锆石 SHRIMP 年龄限定. 地质学报, $2005,79(2): 220-232$

35 刘会涁, 裴先治, 丁仨平, 等. 西秦岭天水市元龙地区新元古代花岗质片麻岩锆石 LA-ICP-MS U-Pb 定年及其地质意义. 地 
质通报, 2006, 25(11): 1315-1320

陈隽璐，张占武，李海平，等。秦岭杂岩中变质侵入体特征。西北地质, 2004, 37(1): 34-39

Creaser R A, Price R C, Wormald R J. A-type granites revisited: Assessment of a residual-source model. Geology, 1991, 19: 163 - 166 [doi]

Barbarin B. A review of the relationships between granitoid types, their origins and their geodynamic environments. Lithos, 1999, 46: $605-626 \underline{\text { doi }]}$

Bonin B, Azzouni-Sekkal A, Bussy F, et al. Alkali-calcic and alkaline post-orogenic (PO) granite magmatism: Petrologic constraints and geodynamic settings. Lithos, 1998, 45: 45-70[doi]

Martin R F. A-type granites of crustal origin ultimately result from open-system fenitization-type reactions in an extensional environment. Lithos, 2006, 91(1-4): 125-136[doi]

Goodge J W, Vervoort J D. Origin of Mesoproterozoic A-type granites in Laurentia: Hf isotope evidence. Earth Planet Sci Lett, 2006, 243: $711-731$ [doi]

Bailey D K. Episodic alkaline activity across Africa: Implications for the causes of continental break-up. In: Storey B C, Alabaster T, Pankhurst R J, eds. Magmatism and the Causes of Continental Break-up. J Geol Soc (London), 1992, 68: 91—98

Burke K, Ashwal L D, Webb S J. New way to map old sutures using deformed alkaline rocks and carbonatites. Geology, 2003, 31: $391-394 \underline{\text { [doi] }}$

Eby G N. Chemical subdivision of the A-type granitoids, petrogenetic and tectonic implications. Geology, 1992, 20: 641-644[doi]

Li X H, Li Z X, Ge W, et al. Neoproterozoic granitoids in South China: crustal melting above a mantle plume at ca. 825 Ma? Precambrian Res, 2003, 122: 45-83[doi]

Li Z X, Li X H, Kinny P D, et al. Geochronology of Neoproterozoic syn-rift magmatism in the Yangtze Craton, South China and correlations with other continents: Evidence for a mantle superplume that broke up Rodinia. Precambrian Res, 2003, 122: 85-109 [doi]

7 Li W X, Li X H, Li Z X. Neoproterozoic bimodal magmatism in the Cathaysia Block of South China and its tectonic significance. Precambrian Res, 2005, 136: 51-66[doi]

Li X H, Li Z X, Sinclair J A, et al. Revisiting the "Yanbian Terrane": Implications for Neoproterozoic tectonic evolution of the western Yangtze Block, South China. Precambrian Res, 2006, 151: 14-30 [doi]

Zhou M F, Yan D P, Kennedy A K, et al. SHRIMP U-Pb zircon geochronological and geochemical evidence for Neoproterozoic arc-magmatism along the western margin of the Yangtze Block, South China. Earth Planet Sci Lett, 2002, 196: 51-67 [doi]

Zheng Y F, Zhang S B, Zhao Z F, et al. Contrasting zircon Hf and O isotopes in the two episodes of Neoproterozoic granitoids in South China: Implications for growth and reworking of continental crust. Lithos, 2007, 96(1-2): 127-150[doi]

Li Z X, Li X H, Kinny P D, et al. The breakup of Rodinia: Did it start with a mantle plume beneath South China? Earth Planet Sci Lett, 1999, 173: 171-181 [doi]

Li X H, Li Z X, Zhou H, et al. U-Pb zircon geochronology, geochemistry and Nd isotopic study of Neoproterozoic bimodal volcanic rocks in the Kangdian Rift of South China: Implications for the initial rifting of Rodinia. Precambrian Res, 2002, 113: 135-155[doi]

李献华, 李正祥, 周汉文, 等. 川西南关刀山岩体的 SHRIMP 锆石 U-Pb 年龄、元素和 Nd 同位素地球化学一一岩石成因与构 造意义. 中国科学 D 辑: 地球科学, 2002, 32(增刊): 60-68

4 李献华, 李正祥, 周汉文, 等. 川西新元古代玄武质岩浆岩的锆石 $\mathrm{U}-\mathrm{Pb}$ 年代学、元素和 $\mathrm{Nd}$ 同位素研究: 岩石成因与地球动 力学意义. 地学前缘, 2002, 9(4): 329-338

5 李献华, 祁昌实, 刘颖, 等. 扬子块体西缘新元古代双峰式火山岩成因: Hf 同位素和 $\mathrm{Fe} / \mathrm{Mn}$ 新制约. 科学通报, 2005, 50(19): $2155-2160$

Zhou M F, Kennedy A K, Sun M, et al. Neo-proterozoic arc-related mafic intrusions in the northern margin of South China: Implications for accretion of Rodinia. J Geol, 2002, 110: 611-618 [doi]

Zhou M F, Ma Y, Yan D P, et al. The Yanbian Terrane (Southern Sichuan Province, SW China): A Neoproterozoic arc assemblage in the western margin of the Yangtze Block. Precambrian Res, 2006, 144: 19-38[doi]

8 Druschke P, Handson A D, Yan Q, et al. Stratigraphic and U-Pb SHRIMP detrital zircon evidence for a Neoproterozoic continental Arc, Central China: Rodinia implications. J Geol, 2006, 114: 627-636[doi]

Zhou J C, Wang X L, Qiu J S, et al. Geochemistry of Meso- and Neoproterozoic mafic-ultramafic rocks from northern Guangxi, China: arc or plume magmatism? Geochem J, 2004, 38: 139-152

周金城，王孝否，邱检生，等. 桂北中-新元古代镁铁质-超镁铁质岩的岩石地球化学. 岩石学报, 2003, 19(1): 9-18

郑永飞, 张少兵. 华南前寒武纪大陆地壳的形成和演化. 科学通报, 2007, 52(1): 1-10

Frost B R, Barnes C, Collins W J, et al. A geochemical classification for granitic rocks. J Petrol, 2001, 42: 2033-2048 [doi]

Anthony E Y. Source regions of granites and their links to tectonic environment: Examples from the western United States. Lithos, 2005, 80: 61-74 [doi]

64 陈丹玲, 刘良, 周鼎武, 等. 东秦岭松树沟超镁铁质岩中辉石巨晶的成因和 ${ }^{40} \mathrm{Ar}-{ }^{39} \mathrm{Ar}$ 定年及其地质意义. 岩石学报, 2002 , 18(3): 355-362

65 Wu R X, Zheng Y F, Wu Y B, et al. Reworking of juvenile crust: Element and isotope evidence from Neoproterozoic granodiorite in South China. Precambrian Res, 2006, 146: 179-212 [doi] 